\title{
What will happen now to India?
}

Will the bomb that killed Mr Rajiv Gandhi last week be the trigger that breaks the subcontinent into smaller pieces? Both India and the rest of us must hope not.

THE assassination last week of Mr Rajiv Gandhi is not just a tragedy, but a danger for us all. Among poor countries, India has the richest promise. Not for nothing is it known as the world's most populous democracy. That the electoral process (during which Gandhi was killed) has survived for more than four decades in such diversity of interest and allegiance - ethnic, religious, economic and geographical, for example - is a marvel. It owes as much to the emphasis laid by the leaders of the independence movement of the 1930 s and 1940 s on the interdependence of urban and rural India as to the vigour with which Mr Rajiv Gandhi's grandfather, Jawaharlal Nehru, embraced the doctrine of secular democratic government. Can it survive a third assassination of a Gandhi? And what, otherwise, will be the consequences?

The observations that India is a contrast of wealth and poverty, and of modernity and backwardness, are familiar but not trite. The contrasts are often shocking to people from elsewhere, puzzled that peasant villages still limp along without elementary sanitary technology in a country that builds its own nuclear power stations and orbital space rockets. The justification of the persistence of these contrasts is a kind of trickle-down theory of social and economic development crumbs spill from rich tables, people who cut their teeth on building nuclear power stations eventually turn their attention to village latrines. There has been some proof, in the past few decades, that the theory works, but not quickly enough to assuage regional passions and discontents. The greatest irony is in the Punjab, where the green revolution first brought a degree of prosperity - and then the separatist movement that became the indirect cause of Rajiv Gandhi's mother's assassination.

\section{Salutary shock}

The gloomy view is that the latest assassination is not so much an occasion that may prove to be a trigger for the break-up of India, but instead a symptom of a process already begun. In that case, there is a chance that the shock the occasion will provoke may have a salutary effect. Gandhi, after all, is but one of more than a hundred people killed so far in the course of this general election. Tamils, Sikhs and even the Hindu fundamentalists of poverty-stricken Bihar may now be persuaded that the goals behind the communal violence of the past few years are not prizes for which lives (often other people's) are worth sacrificing, but are empty prizes. Allunion India may be virtually unmanageable, but a splintered India would be even nearer chaos.
Even within India, the benefits of union are too often overlooked. Not the least of these is what union has done for India's intellectual life. Since independence, the centre has created throughout provincial India universities in the image of India's best, both by the efforts of enlightened public servants at the University Grants Committee and by the private foundation of institutions as different as the Tata Institute at Bombay and the Raman Institute at Bangalore, both (among others in India) now research centres of international repute. In short, the centre has made possible the creation in India of a respected intellectual cadre whose chief misfortune is that so many of its members choose the brighter opportunities overseas. Even the Gupta business at Chandigarh, with which the university has not yet dealt effectively, may be taken as a measure of the respect accorded to intellectual pursuits; would people take such trouble to simulate true scholarship if it were otherwise?

\section{Secularism}

Socially, the benefits of union are even greater. There are, for example, more Muslims ( 75 million plus) in India than in any of the predominantly Muslim states except Indonesia, yet for most of India's independence, tensions familiar elsewhere have been abated by the secularism of the state. Would that civility persist if India were broken into pieces? The centre has also given even the poor a sense that civic rights are there to be exercised, even in the face of a bureaucracy whose bumbledom is by now legendary. The union has been less successful at spreading the benefits of technical change in rural India. Indirectly, that may have been another cause of last week's tragedy.

From the outside, India's union has been an even greater benefit. Since independence, there has been a single voice to speak for getting on for 1,000 million people. Although this collective message has often irritated people in the West, on questions such as the Nuclear Non-Proliferation Treaty for example, even those who have been most maddened by India's prevarications and casuistry internationally will readily acknowledge how much less comfortable it would be if there were a dozen new voices on the international scene preoccupied with regional issues - Kashmir, perhaps, or the Tamil population of Sri Lanka. That is yet another reason why India must hang together. In a society still tolerant of the notion that there are leaders and the led, that is a challenge for the intellectual community of India. The goal must be to make the poor of India prosperous. 